\title{
THE EFFECTS OF IMPRESSION MANAGEMENT TACTICS ON EMOTIONAL EXPRESSIONS: RESEARCH ON BANKING SECTOR
}

\author{
* Semih SORAN \\ ** M.Onur BALKAN \\ *Ozyegin University, Turkey \\ **Afyon Kocatepe University, Turkey
}

\begin{abstract}
The main object of this paper, which should be considered a descriptive survey in the general sense, is to investigate the relationship between emotional expressions and impression management tactics. The related literature on emotions, the relationship between emotional expressions and impression management tactics could not be found. It is hypothesized that the use of emotional expressions will varyaccording to which impression management tactic is used. Two different surveys were used in order to measure and assess the emotions expressions and impression management tactics. The survey conducted on 225 employees of the banking sector. Data, obtained from questionnaires analyzed through the SPSS statistical packaged software. The results show that, the supplication factor had a positive and significant effect on positive expressions; the intimidation factor had a positive and significant effect on negative expressions. In addition, intimidation and job-involvement had a negative and significant effect on intimacy.
\end{abstract}

Keywords: Emotional expressions, impression management, feelings, emotions

\section{INTRODUCTION}

Emotions consist of psychological and physiological factors. The social environment can be added to this phenomenon (Gardner, 1999). Emotions are indispensable for understanding the dynamics of the working environment (Ashkansky, 2000). Until the mid-1980s to the 1930s, feelings discussed more than on job satisfaction (Brief \& Weiss, 2002). Studies on emotions can be examined under various subject headings: Emotional Labor, Emotional Intelligence, Emotional Events Theory and PositiveNegative Feelings (Briner, 2005). Organizations must put emotions and emotional intelligence at the center of their plans (Fineman, 2003). There is a very important role of emotions in organizational structure as well as community and in private life. Emotions are the shape factor that directly affects the decisions in management mechanism within the organizational structure. A study conducted among 278 persons in an organization clears that $77 \%$ of the employees are breeding hostility to at least one person at work (Miner, 1990). The foundation of creating a healthy organization is understand and managing emotions at work. In daily life lot of positive and negative feelings is lived within the organization. Emotional expressions are our way to make the others know about our emotional mood. We should take into account both emotions and emotional expressions in the organization life.

Impression management is defined as a course to affect the view others have about oneself, by checking the self-reflected information (Demir, 2002; Gardner\& Martinko,1988; Leary\&Kowalski,1990; Leary,1996; Rosenfeld, Giacalone\&Riordian,1995; Rind\&Benjamin,1993; Basım\&Tatar\&Şahin,2006). The connected literature on emotional expressions, the relationship between emotional expressions and impression management strategies, could not be found. The primary goal of the study is to try to fill the gap in the literature by exploring the relationship between emotional expressions and impression management tactics 


\section{LITERATURE REVIEW AND HYPOTHESES}

\section{Emotions and Emotional Expressions}

Executive leaders and directors are required to succeed the method of "sense" and "emotion" very well to accomplish organizational aims (Lee, 2002). Organizations need to manage all the emotions and feelings and concepts that affect individual health and performance (Gross, 1999). Business life dealing with this issue has increased in seriousness because, the effect of emotions in decision making cleared with academic studies. There is a need to find the path to the correct leadership of emotions. Emotions in the organization help to identify thoughts about the presence and desire to work (Jackson, 2006). Emotions provide information on what causes, and how it is done. Suppress feelings prevents the achievement of this information. Most people hear discomfort about understand their own moods and manage the issue in a positive way. They deny or suppress their feelings from time to time (Barutçugil, 2004). There are various reasons for this. To be "to the desired structure, the appropriate person" in organizations or in the social life, feelings of the individual shaped by teachers, managers, bosses and so on, starting from the beginning of school years. Apart from this, the individual took place in military or organizations that he could not express his feelings and more stringent rules applied (Stearns, 1986). There are environmental and physical factors in organizations that you can or cannot express your feelings freely. However, the suppression of emotions does not cause feelings to disappear, but rather an increase in violent. Therefore, the feelings need to manage and to cope with. In social life managing feelings means that, in contrast to the suppression of feelings, understand them and match the feeling to situations to take advantage of it efficiently. These people who have the skills to manage their feelings are more productive (Goleman, 2000). Feelings are also concerned with social intelligence because it means verbal and nonverbal communication with other people, working in a group etc. (Goleman, 2006). Carussco and Salovey listed properties of administrators, who are capable or incapable of managing his own and others feelings (Carussco ve Salovey, 2010). When examining the past assessment of emotion in one dimension, recent studies have suggested that emotion structure occurred independently in two basic dimensions. These dimensions are positive and negative feelings (Gençöz, 2000). Positive and negative emotions in the workplace play a key role in the decision-making and organizational conflicts (Kafetsios, 2007). Negative feelings have much more effect on employees (Silvia, 2006). Basch and Croparanzo reported in their studies that these negative emotions in the workplace reduced product quality (Toegel, 2007). But researchers discuss about which feelings are exactly primary or secondary. (Goleman, 2009). Some psychologists are seen feelings as basically subjective moods and only find verbal description worthy of consideration of people living the feelings. Some other scientists, relying on test scores only. Some scientists insist that reliance on only the neural and biochemical measurements of physiological stimuli (Barutçugil, 2004). Measurement of emotions can be counted of the three basic methods. These methods are the individual test method, physically test method and the methods of brain imaging techniques. Individual test method is the most commonly used. This method is inexpensive and easy. Difficulty in this method can be giving meaning to emotions. Physically test method is applicable to both written and visually physically tests method use facial expressions instead of words. These methods include: Self-Assessment Model (SAM) and Premo. The available methods of brain imaging techniques are EEG, MEG, PET and fMRI (Sorensen, 2008).

\section{Impression Management}

The idea of impression management is common in the discussion of business activity. Impression management is said to be important to corporations and individuals, and to individuals both within their organizations and in contact with organizational clients (Provis, 2010). Impression management theorists suggest that a primary human motive, both inside and outside organizations is to avoid being evaluated negatively (Jain, 2012). Impression management is defined as a course to affect the view others have about oneself, by checking the self-reflected information. Goffman (1959) began the interest into the study of impression management by introducing a dramaturgical framework describing the way one presents them and how others might perceive that presentation (Cole, Rozelle, 2011). In essence, an actor consciously chooses a behavior to present to the audience in anticipation of a desired effect. Assuming the audience responds in the way that the actor intended, the actor will continue to use the particular strategy. Central to this process is the understanding of the strategy used, 
the personal motivation behind the strategy choice, the specific target audience and the situational factors in the environment where the impression management occurs. This theory provides a direct link of interaction between the actor and the organizational audience (Cole, Rozelle, 2011). As soon as we meet someone, both parties automatically and/or consciously form a judgment about the other party. This impression formation activity, based on very limited cues, is an important and universal trend for everyone (Taylor,1997). Consequently, we can say that, managing these impressions others will have about one is a very important, purposeful, dynamic, strategic process, which affects one's life deeply (Sallot, 2002). Researchers suggest there is a need for those for organizational settings to understand the basic elements or constructs involved in impression management (Crane, \& Crane, 2004).

As it is true in other settings, individuals try to sculpture their relationships in organizational settings as well. Impression management turns out to be a continuous activity among newcomers, used in order to be accepted by the organization, and among those who have matured with the organization, used in order to be influential (Demir, 2002). Besides the conceptualization of impression management, many have proposed goal theory regarding impression management. For some, the use of impression management tactics has the specific goal of appearing attractive or liked (Cole, Rozelle, 2011). This, in fact, is what most research focuses on. Another theory, offered by Jones \& Pittman (1982), proposes that the underlying goal of the strategies used in impression management has to do with the protection and maintenance of power. This power, maintained or increased through the use of impression management strategies, becomes the influence used for control in a person's social environment (Cole, Rozelle, 2011).

There are two main approaches in impression management; universal and multiple contextual approaches. The universal approach has been researched from decades and focuses on a person exhibiting to be an individual actor. It further includes detailed analysis, focusing on impression management in a culture liberated environment. On the contrary, multiple contextual approaches discusses the forming of a particular impression with different contexts including general traditions and cultures; group socio-economic and demographic distinctiveness and specific situations and conditions and organizational individuality such as managerial roles and working categories and statuses (Nayar, Raja, 2012).

Impression management strategies are a commonplace part of everyday life, it's impact on an organization's culture and performance is important (Gardner, 1992). Jones and Pitman (1982) offered five strategies of impression management: ingratiation, self-promotion, exemplification, intimidation and supplication. Use of a particular strategy depends on what attribution the person is seeking from the audience. In addition, it should be noted that the strategies presented do not have to exist or be used independently of one another (Jones \& Pittman, 1982). This would mean actors can use one or any number of the strategies to influence their audience's feelings and perceptions of the situation.

The intimidator tries to convince his target that he is dangerous (Jones \& Pittman, 1982). Intimidation is an impression management strategy designed to increase the credibility of ones threats and in turn enhance the probability that the target will comply to the actors demands for agreement (Tedeschi \& Riess, 1981). Another way of stating it is that " the intimidator advertises his available power to create discomfort or all kinds of psychic pain”(Jones \& Pittman, 1982). Jones (1990) pointed out that individual using intimidation try to look stubborn and obstinate. However, these strategies have risk of being seen unfavorable. The people involved in intimidation are likely to be viewed tenacious and forceful persons. They are prone to the risk of getting an adverse reaction of their tough behavior (Arif, 2011). Being liked is contrary to the goals of an intimidator. Fear, generated as an emotion in others, helps the intimidator use their available power to coerce another into action or submission (Cole, Rozelle, 2011).

The tactic of ingratiation is a set of linked acquisitive impression management tactic that have as their shared goal making the individual more liked and attractive to others. It could in other words also be called " attraction management". The task and challenge of the ingratiator is to find out what the audience findsattractive in and individual and then provide it to them (Schlenker, 1980). Tedeschi and Melburg (1984) conceptualized four impression management techniques, and they defined Ingratiation as " a collection of forceful tactics with the aim of gaining the admiration of an audience, 
who has the authority to offer significant rewards for the actor"(Arif, 2011). The use of ingratiation as an impression management strategy seeks to help an individual attain the social acceptance they desire (Cole, Rozelle, 2011).

In exemplification strategy, the person shadows the impression of overly dedicated and committed to his/her job on the supervisors, while creating a feeling of guilt among others. When a person says," I will finish this work at any cost, even for that I have to suffer personal loss, you please go and enjoy." he is using this strategy. In this strategy, actors portrays such behaviors to make them appear like Ideals employees, working or showing to work beyond the call of the duty when using this tactic (Arif , 2011). Jones and Pittman (1982) contend that some use the arousal of guilt to get others to emulate the behaviors presented. Examples of this might include the radical protester that gets others to follow their actions by convincing them that violence is the only way. Another, less evil example might be that of a political figure that charismatically convinces the audience to stand up to injustice and unfair laws (Cole, Rozelle, 2011).

The self-promoter wants to achieve an attribution of competence. It may seem in first instance another form of ingratiation, but the self-promoter wants to use the self descriptive communication to be seen as competent instead of aslikeable. The goal when using this strategy is usually an immediate one such as getting admitted into a university or a new job(Tedeschi \& Riess, 1981). Self-promotion is generally considered an aggressive strategy (Arif, 2011). The negative potential of self-promotion can bring about feelings of jealousy or resentment from others. In addition, individuals that are proactively promoting their actions and skills can be seen as conceited or arrogant by those that might not actually have evidence or personal knowledge that what an individual is claiming is true (Jones \& Pittman, 1982). Self-promotion is most often used when the chance of their claims being challenged or discredited is low (Rosenfeld, 1995). Next to this it was also found that the occurrence of selfpromotion increases when individualshave the opportunity to openly impress someone with a higher status about their competence (Giacalone \& Rosenfeld, 1986).

The last self-presentational strategy can be used by individuals who are not able to use any of the strategies presented previously, as it involves exploiting ones weaknesses. The individual emphasizes his own dependence and weakness to obtain help from a more powerful other. By advertising their lack of ability, they attempt to activate a powerful social rule the norm of social responsibilitythat says you should help those who are in need (Rosenfeld, 1995). In supplication strategy the person advertises his weak areas in order to get sympathy. The person portrays himself as helpless to get the help from other. Supplication is a strategy through which individuals publicize their shortcomings in an effort to be viewed as disadvantaged. Supplication entails actions that persons employ in order to portray a personality of humble and helpful. Supplication is considered as a passive strategy. Employees may engage in supplication to seek the help and support from others (Arif, 2011). Reasons for presenting behaviors of helplessness include simply not wanting to do a task, to avoid criticism for making a mistake, and actually not knowing how to get something or accomplish something (Leary, 1996).

\section{Development of Hypotheses}

Emotional expressions and impression management are topics of particular interest to organizations. This study aims to link impression management tactics and emotional expressions. Because of that we propose positive expressions and intimacy have relationship with positive impression management tactics; while negative expressions have relationship with negative impression management tactics.

H1: There is a positive relationship between self-promotion and positive emotional expressions.

$\mathrm{H} 2$ : There is a positive relationship between exemplification and positive emotional expressions.

H3: There is a positive relationship between supplication and positive emotional expressions.

$\mathrm{H} 4$ : There is a positive relationship between self-promotion and intimacy.

H5: There is a positive relationship between exemplification and intimacy.

H6: There is a positive relationship between supplication and intimacy.

$\mathrm{H} 7$ : There is a positive relationship between intimidation and negative emotional expressions.

H8: There is a positive relationship between job-involvement and negative emotional expressions. 


\section{METHODOLOGY}

\section{Research Goal}

In this research we aim to find the effects of impression management strategies on emotional expressions. To test the assumption, two scales were conducted.

\section{Sample and Data Collection}

The contributors in the current study comprised 225 banking employees from 10 banks in Turkey. The banks included nearly 400 employees completely and participants were selected arbitrarily. Questionnaires were spread by the researcher to every participant in different sessions in all of the banks. When the returned questionnaires were examined, 25 were invalid. As a result, a total of 200 valid responses were used in the research. The samples included $105(52,5 \%)$ female and $95(47,5 \%)$ male volunteers. Their education level was ; $172(86 \%)$ graduate degree, $14(7 \%)$ master's degree, 7 $(3,5 \%)$ associate degree, $4(2 \%)$ high school degree and $3(1,5 \%)$ doctorate degree. Participants had been working in their banks; $86(43 \%)$ for 3-10 years, 49 (24,5\%) for 10 and more years, $40(20 \%)$ for $1-3$ years, $25(12,5 \%)$ for 1 and lower years.

\section{Analyses and Results}

Data produced in this study were collected by survey. The survey consisted of three measures. In the first part questions about the demographic characteristics of banking employees; in the other two parts questions designed to measure impression management and emotional expressions were asked.

Impression management tactics were measured by a scale taken from Bolino and Turnley (1999), based on the classification system proposed by Jones and Pittman (1982). The translation and edition of the scale to Turkish was made by Basim(2006). The measure included 22 items, each item was answered through a five-point Likert scale ranging from " $1=$ strongly disagree" to " $5=$ strongly agree." In the present study, the Cronbach's a coefficient for the scale was .68.

Emotional expressions were measured by a scale taken from King and Emmon (1990), the translation and adaptation of the scale to Turkish was made by Kuzucu(2011). The measure included 15 items, each item was answered via a seven-point Likert scale ranging from " $1=$ strongly disagree" to "7=strongly agree." In the present study, the Cronbach's a coefficient for the scale was .74.

The Validity of the Measures: To ensure the validity and reliability of the study variables, explanatory factor analysis was conducted by using SPSS software.

The impression management measure produced five factors upon factor analysis. The first factor named "Self-promotion", explained $22.42 \%$ of the total variance. The second factor was named "Supplication" and it explained $14.01 \%$ of the variance. "Exemplification" the third factor with a variance of $13.30 \%$, was followed by "Intimidation" (10.50\%) and "Job-involvement" (8.56\%). The factors all together explained $68.80 \%$ of the variance. KMO Bartlett's Test of Sphericity was .759.

The Cronbach's alphas for the factor-based subscales were: Self-promotion ( 8 items), a $=.90$; Exemplification (4 items), $a=.85$; Intimidation ( 3 items), $a=.83$; Supplication ( 5 items), $a=.83$; and Job-involvement ( 2 items), $\mathrm{a}=.91$. The Cronbach's alphas for the total scale was $\mathrm{a}=.71$.

The emotional expression scale yielded three factors upon factor analysis. The first factor named "intimacy", explained $30.12 \%$ of the total variance. The second factor was named "positive", and it explained $28.92 \%$ of the variance. The third factor was named "negative", and it explained $23.40 \%$ of the variance. The factors all together explained $82.44 \%$ of the variance.The Cronbach's alphas for the factor-based subscales were: Intimacy ( 6 items), $a=.66$; Positive (5 items), a = .72; Negative (4 items), $\mathrm{a}=.94$. The Cronbach's alphas for the total scale for the two samples were $\mathrm{a}=.74$. 


\begin{tabular}{|c|c|c|c|c|c|}
\hline IMPRESSION MANAGEMENT & $\begin{array}{c}\text { Self- } \\
\text { promotion }\end{array}$ & Supplication & Exemplification & Intimidation & $\begin{array}{c}\text { Job- } \\
\text { involvement }\end{array}$ \\
\hline $\begin{array}{l}\text { Let others know that you are valuable to the } \\
\text { organization. }\end{array}$ &, 871 & & & & \\
\hline $\begin{array}{l}\text { Make people aware of your talents or } \\
\text { qualifications. }\end{array}$ &, 825 & & & & \\
\hline Make people aware of your accomplishments. &, 800 & & & & \\
\hline $\begin{array}{l}\text { Compliment your colleagues so they will see you } \\
\text { as likable. }\end{array}$ &, 774 & & & & \\
\hline $\begin{array}{l}\text { Praise your colleagues for their accomplishments } \\
\text { so they will consider you a nice person. }\end{array}$ &, 772 & & & & \\
\hline $\begin{array}{l}\text { Take an interest in your colleagues' personal lives } \\
\text { to show them that you are friendly. }\end{array}$ &, 762 & & & & \\
\hline $\begin{array}{l}\text { Do personal favours for your colleagues to show } \\
\text { them that you are friendly }\end{array}$ &, 719 & & & & \\
\hline Talk proudly about your experience or education. & ,713 & & & & \\
\hline $\begin{array}{l}\text { Try to gain assistance or sympathy from people by } \\
\text { appearing needy in some areas. }\end{array}$ & &, 801 & & & \\
\hline $\begin{array}{l}\text { Pretend to know less than you do so you can avoid } \\
\text { an unpleasant assignment. }\end{array}$ & &, 778 & & & \\
\hline $\begin{array}{l}\text { Act like you need assistance so people will help } \\
\text { you out. }\end{array}$ & &, 769 & & & \\
\hline $\begin{array}{l}\text { Act like you know less than you do so people will } \\
\text { help you out. }\end{array}$ & &, 758 & & & \\
\hline $\begin{array}{l}\text { Pretend not to understand something to gain } \\
\text { someone's help. }\end{array}$ & &, 775 & & & \\
\hline $\begin{array}{l}\text { Come to the office at night or on weekends to show } \\
\text { that you are dedicated. }\end{array}$ & & &, 892 & & \\
\hline Arrive at work early to look dedicated. & & & ,892 & & \\
\hline $\begin{array}{l}\text { Stay at work late so people will know you are hard } \\
\text { working }\end{array}$ & & & ,834 & & \\
\hline $\begin{array}{l}\text { Try to appear busy, even at times when things are } \\
\text { slower. }\end{array}$ & & &, 701 & & \\
\hline $\begin{array}{l}\text { Let others know you can make things difficult for } \\
\text { them if they push you top far. }\end{array}$ & & & &, 871 & \\
\hline $\begin{array}{l}\text { Use intimidation to get colleagues to behave } \\
\text { appropriately. }\end{array}$ & & & &, 837 & \\
\hline $\begin{array}{l}\text { Be intimidating with co-workers when it will help } \\
\text { you get your job done. }\end{array}$ & & & &, 813 & \\
\hline $\begin{array}{l}\text { Deal forcefully with colleagues when they hamper } \\
\text { your ability to get your job done. }\end{array}$ & & & & & ,948 \\
\hline $\begin{array}{l}\text { Deal strongly or aggressively with co-workers who } \\
\text { interfere in your business. }\end{array}$ & & & & & ,939 \\
\hline
\end{tabular}

Total Explained Variance for Impression Management \% 68,80 
Table-2: Factor analysis results for emotional expressions

\begin{tabular}{|l|l|l|l|}
\hline EMOTIONAL EXPRESSIONS & Intimacy & Positive & Negative \\
\hline When I really like someone they know it. &, 889 & & \\
\hline I apologize when I have done something wrong. &, 880 & & \\
\hline I often touch friends during conversation. &, 874 & & \\
\hline $\begin{array}{l}\text { Whenever people do nice things for me, I feel "put on the spot” and have trouble } \\
\text { expressing my gratitude. }\end{array}$ &,- 848 & & \\
\hline I often tell people that I love them. &, 839 & & \\
\hline I show that I like someone by hugging or touching that person. &, 834 & & \\
\hline I often laugh so hard that my eyes water or my sides ache. & &, 969 & \\
\hline Watching television or reading a book can make me laugh out. & &, 967 & \\
\hline $\begin{array}{l}\text { When I am alone, I can make myself laugh by remembering something from the } \\
\text { past. }\end{array}$ & &, 965 & \\
\hline I laugh a lot. & &, 950 & \\
\hline My laugh is soft and subdued. & &,- 714 & \\
\hline People can tell from my facial expressions how I am feeling. & & &, 958 \\
\hline If someone makes me angry in a public place, I will cause a scene. & &, 945 \\
\hline I always express disappointment when things don't go as I'd like them to. & &, 903 \\
\hline When I am angry people around me usually know. & &, 903 \\
\hline
\end{tabular}

Total Explained Variance for Emotional Expressions \% 82,44

Table-3: Cronbach alpha values and source of scales

\begin{tabular}{lcccc}
\hline \multicolumn{1}{c}{ Factors } & $\begin{array}{c}\text { Number } \\
\text { of }\end{array}$ & $\begin{array}{c}\text { Scale } \\
\text { Format }\end{array}$ & $\begin{array}{c}\text { Cronbach } \\
\text { Alpha }\end{array}$ & Scale Sources \\
\hline Self-promotion & 8 & LRFa & 0,90 & Basim(2006) \\
Supplication & 5 & LRFa & 0,83 & Basim(2006) \\
Exemplification & 4 & LRFa & 0,85 & Basim(2006) \\
Intimidation & 3 & LRFa & 0,83 & Basim(2006) \\
Job-involvement & 2 & LRFa & 0,91 & Basim (2006) \\
Intimacy & 6 & LRFb & 0,66 & Kuzucu (2011) \\
Positive Expressions & 5 & LRFb & 0,72 & Kuzucu (2011) \\
Negative Expressions & 4 & LRFb & 0,94 & Kuzucu (2011) \\
Notes: a LRF - Likert Response Format (Five point: 1=strongly disagree to 5=strongly agree) \\
$\quad$ b LRF - Likert Response Format (Seven point: 1=strongly disagree to 5 = strongly agree)
\end{tabular}


Table-4:Descriptive statistics, reliability scores and inter-correlations between variables

\begin{tabular}{lcccccccccc}
\hline Factor & Mean & SD & $\mathbf{1}$ & $\mathbf{2}$ & $\mathbf{3}$ & $\mathbf{4}$ & $\mathbf{5}$ & $\mathbf{6}$ & $\mathbf{7}$ & $\mathbf{8}$ \\
\hline Positive & 3.68 & 1,14 & $(.72)$ & & & & & & & \\
Intimacy & 4.25 &, 90 &, $17^{*}$ & $(, 66)$ & & & & & & \\
Negative & 4,27 & 1,49 &, 10 &, 66 & $(, 94)$ & & & & & \\
Self-promotion & 2,47 &, 65 &,- 10 &,- 095 &,- 059 & $(, 90)$ & & & & \\
Exemplification & 2,42 &, 72 &, 127 &,- 020 &, 10 &,- 011 & $(, 85)$ & & & \\
Intimidation & 2,41 &, 70 &,- 114 &, 109 &, $210^{* *}$ &,- 007 &,$- 253^{* *}$ & $(.83)$ & & \\
Supplication & 2,34 &, 69 &,- 112 &, $142^{*}$ &, 046 &,- 080 &, 013 &,- 123 & $(.82)$ \\
Job-involvement & 2,01 &, 97 &,- 082 &,- 064 &, 035 &,- 094 &,- 065 &, $249 * *$ &, 076 & $(.91$ \\
\hline
\end{tabular}

Table-4 presents the mean and standard deviations of all measures and the correlation coefficients between the variables. These results indicated statistically a positive correlation between intimacy and positive emotions ( $\mathrm{r}=.17, \mathrm{p}<.05)$, a positive correlation between negative emotions and intimidation $(\mathrm{r}=.210, \mathrm{p}<.01)$, a negative correlation between exemplification and intimidation $(\mathrm{r}=-.253, \mathrm{p}<.01)$, a positive correlation between intimacy and supplication $(r=.142, p<.05)$ and a positive correlation between intimidation and job-involvement $(r=, 249, \mathrm{p}<.01)$

Table-5: Hierarchical regression analysis results for emotional expressions

\begin{tabular}{|l|l|l|l|l|l|l|}
\hline \multirow{2}{*}{ Depended Variable } & \multicolumn{2}{|c|}{ Positive } & \multicolumn{2}{c|}{ Intimacy } & \multicolumn{2}{c|}{ Negative } \\
\cline { 2 - 7 } & \multicolumn{1}{|c|}{ Model 1 } & \multicolumn{1}{c|}{ Model 2 } & Model 1 & \multicolumn{1}{c|}{ Model 2 } & \multicolumn{1}{c|}{ Model 1 } & \multicolumn{1}{c|}{ Model 2 } \\
\cline { 2 - 7 } & \multicolumn{1}{|c|}{$\boldsymbol{\beta}$} & $\boldsymbol{\beta}$ & \multicolumn{1}{c}{$\boldsymbol{\beta}$} & $\boldsymbol{\beta}$ & $\boldsymbol{\beta}$ \\
\hline \multirow{2}{*}{ Gender } & $0,167^{*}$ & $0,170^{*}$ & 0,113 & 0,12 & 0,103 & 0,10 \\
\hline Job duration & $-0,58$ & 0,004 & 0,00 & $-0,20$ & $-0,44$ & $-0,12$ \\
\hline Education &,- 018 & $-0,074$ & $-0,64$ & $-0,40$ & $-0,46$ & $-0,39$ \\
\hline Self-promotion & & $-1,09$ & & $-0,86$ & & $-0,46$ \\
\hline Exemplification & & 0,97 & & 0,005 & & 0,47 \\
\hline Intimidation & & $-0,96$ & & $-0,162 *$ & & $0,219^{* * *}$ \\
\hline Supplication & & $0,145^{*}$ & & 0,157 & & 0,00 \\
\hline Job-involvement & &,- 64 & & $-0,132 *$ & & 1,095 \\
\hline$\Delta \mathbf{R}^{2}$ & 0,18 & 0,90 & 0,018 & 0,072 & 0,00 & 0,69 \\
\hline$\Delta \mathbf{F}$ & 0,161 & $2,368^{*}$ & 1,185 & 1,864 & 1,011 & 1,781 \\
\hline
\end{tabular}

$* \mathrm{p}<0,05 * * \mathrm{p}<0,01 * * * \mathrm{p}<0,001$

To explore whether the independent variables had a significant impact on the dependent variables, hierarchical regression analyzes were conducted. Table-5 shows the regression analysis results for each emotional dimension. In the regression analysis, in model one, demographic variables (gender, job duration, and education) were first entered to control their effects, after which self-promotion, 
exemplification, intimidation, supplication and job-involvement were added in step two. After controlling for demographics in model one, only gender had significant effect on positive emotional expressions (gender $\beta=.167, \mathrm{p}<.005$ ). In model two, gender and supplication had a significant positive effect on positive expressions (gender $\beta=.170, \mathrm{p}<.005$ and supplication $\beta=.145, \mathrm{p}<.005$ ). Intimidation and job-involvement had a significant negative effect on intimacy (intimidation $\beta=$ $.162, \mathrm{p}<.005$ and job-involvement $\beta=-.132, \mathrm{p}<.005)$. Intimidation had a significant positive effect on negative expressions (intimidation $\beta=.219, \mathrm{p}<.001$ ). The results show that, supplication had a positive and significant effect on positive expressions; intimidation had a positive and significant effect on negative expressions as hypothesized. In addition, intimidation and job- involvement had a negative and significant effect on intimacy.

Thus, hypotheses 3: (There is a positive relationship between supplication and positive emotional expressions) and hypotheses 7: (There is a positive relationship between intimidation and negative emotional expressions) were accepted. Hypotheses 1: (There is a positive relationship between selfpromotion and positive emotional expressions), hypotheses 2: (There is a positive relationship between exemplification and positive emotional expressions), hypotheses 4: (There is a positive relationship between self-promotion and intimacy), hypotheses 5: (There is a positive relationship between exemplification and intimacy), hypotheses 6: (There is a positive relationship between supplication and intimacy) and hypotheses 8: (There is a positive relationship between jobinvolvement and negative emotional expressions) were rejected.

\section{CONCLUSION}

One of the objectives of the present study was to fill the gap the literature of emotion and emotional expressions in correlations among impression management tactics. These results indicated statistically a positive correlation between intimacy and positive emotions $(\mathrm{r}=.17, \mathrm{p}<.05)$, a positive correlation between negative emotions and intimidation $(\mathrm{r}=.210, \mathrm{p}<.01)$, a negative correlation between exemplification and intimidation $(\mathrm{r}=-.253, \mathrm{p}<.01)$, a positive correlation between intimacy and supplication $(\mathrm{r}=.142, \mathrm{p}<.05)$ and a positive correlation between intimidation and job-involvement. We expected to find statistically significant correlations between more variables. Also the results showed us the most used expression factor was the negative expression factors (mean: 4,27) followed by intimacy (mean: 4,25) and positive expressions (mean: 3,68).

The hierarchical regression analysis displayed that, gender and supplication had a significant positive effect on positive expressions (gender $\beta=.170, \mathrm{p}<.005$ and supplication $\beta=.145, \mathrm{p}<.005$ ); intimidation and job-involvement had a significant negative effect on intimacy (intimidation $\beta=-.162$, $\mathrm{p}<.005$ and job-involvement $\beta=-.132, \mathrm{p}<.005)$; intimidation had a significant positive effect on negative expressions (intimidation $\beta=.219, \mathrm{p}<.001$ ). In addition, intimidation and job-involvement had a negative and significant effect on intimacy.

The main finding of this study is that the emotional expressions one uses changes according to what kind of impression management tactics are used. So, it can be said that some emotional expressions and impression management strategies are "positive" and some are "negative". We can consider "positive expression" and "intimacy" as positive and "negative expression" as negative for the emotional expressions. On the other hand we can consider "self-promotion", "exemplification" and "supplication" as positive, "intimidation" and "job-involvement" as negative for the impression management tactics.

In the current study we expected to find positive impression management tactics effect positive emotional expressions while negative impression management tactics effect negative emotional expressions. The findings showed that one positive impression management factor had a positive effect on positive expressions. Besides, one negative impression management factor had a positive effect on negative expressions.

Without any doubt, these findings are limited by the sample and the assessment instruments used in the present study. This research conducted on banking employees in Turkey; the findings might not be transferable to other organizations. Thus, it is recommended that further researches can be conducted 
Journal of Global Strategic Management | V. 7 | N. 1 | 2013-June | isma.info | 154-165 | DOI: 10.20460/JGSM.2013715681 on different sectors and also in different countries for the generalizability of the results. The fact that

the present sample is composed of only 200 personnel is another drawback of this study. 


\section{REFERENCES}

Arif, Ahmad, Syed Hasan Mohammad Rizvi, Quaiser Abbas, Shoaib Akhtar, Mohammad Imra (2011), Impact of Impression Management on Performance Rating, Interdisciplinary Journal of Contemporary Research in Business, Vol 3, No 2, 711-729 pp.4.

Ashkansky, Neal(2000), Emotions In The Workplace Research, Theory and Practice.

Barutçugil, İsmet (2004), Organizasyonlarda Duyguların Yönetimi, İstanbul, pp.74-84.

Basım, Nejat, İlker Tatar, Nesrin Hisli Şahin(2006), İzlenim Yönetiminde Kendilik algısı, Kontrol Odağı, Mesleki Hedeflere Ulaşma Düzeyi ve Stres: Bir Kamu Sektörü Örneği.

Brief, Arthur \& H. Weiss (2002), Organizational Behavior: Affect In The Workplace, Annu. Rev. Psycho, pp.279-307.

Briner, Rob (2005), Psychological Research Into The Experience Of Emotion At Work. Definitely Older, But Are We Any Wiser?,pp.290.

Cole, Amy Y., Elizabeth J. Rozelle (2011), Emotional Intelligence And Impression Management: A Theoretical Framework, Insights Journal, Volume 2011, Issue 1, pp.93-114.

Crane\&Crane, E.(2004), Usage and Effectiveness of Impression Management Strategies in Organizational Settings, Journal of Group Psychotherapy Psychodrama and Sociometry.

Demir, K.(2002), Türkiye'deki Resmi ve Özel Lise Öğretmenlerinin İzlenim Yönetimi, Yayınlanmamış Doktora Tezi, Ankara Üniversitesi Eğitim Bilimleri Enstitüsü .

Fineman, Stephan(2003), Understanding Emotion At Work.

Gardner, W. L. (1992), Lessons in Organizational Dramaturgy: The Art of Impression Management, Organizational Dynamics, pp.33-46.

Gardner, W. L.,Martinko, M. J. (1988). Impression management in organizations. Journal of Management, 14, pp.321-338.

Gardner, Wendi (1999), Emotion, Annu.Rev. Psychol, s.191-214.

Gençöz, Tülin (2000), Pozitif ve Negatif Duygu Ölçeği Geçerlilik ve Güvenirlik Çalışması, Türk Psikoloji Dergisi, 2000, Cilt: 15, Say1: 46.

Giacalone, R. A., \& Rosenfeld, P. (1986). Self-Presentation and Self-Promotion in an Organizational Setting. Journal of Social Psychology, 126(3), pp.321.

Goffman, E.(1959), The Presentation of Self in Everyday Life,Garden City,NY,Doubleday.

Goleman, Daniel (2000), "Duygusal Yeterlilik", Executive Excellence, Ocak 2000, pp.73.

Goleman, Daniel (2006), Sosyal Zekâ, İnsan İlişkilerinin Yeni Bilimi, İstanbul, Varlık Yayınları,pp.106-109.

Goleman, Daniel (2009) , Duygusal Zekâ, İstanbul,Varlık Yayınları,pp.225.

Gross, J.J.(1999), Emotion Regulation: Past, present, future, Cognition and Emotion, pp:551.

Jackson, Paul (2006), Developments in Work and Organizational Psychology: Implications for International Business, pp.185-186.

Jain, Ajay K. (2012), Moderating Effect of Impression Management On the Relationship of Emotional Intelligence and Organizational Citizenship Behavior, Institute of Behavioral and Applied Management, pp.86-107

Jones, E. (1990), Interpersonal perception, New York: W.H. Freeman and Company.

Jones, E.E \& Pittman, T.S. (1982). Toward a General Theory of Strategic Self-Presentation, Psychological Perspectives On The Self, pp.231-262. 
Kafetsios, Konstantinos (2007), Emotional Intelligence and Emotion Regulation on Affect at Work and Job Satisfaction, Work Organization and Emotion, pp.72

Kuzucu,Yaşar (2011), Adaptation of the Emotional Expression Questionnaire: Validity and Reliability Studies.

Lee, David (2002), How Employee Emotions Affects Your Organization's Ability to Complete pp.3.

Leary, M. R. (1996), Self-presentation: Impression Management and Interpersonal Behaviors. Boulder, CO: Westview Press, Inc.

Leary, M. R., \& Kowalsky. R. M. (1990). Impression Management: A literatüre reviev and twocomponent model. Psychological Bulletin, 107(1), 34-47

Miner, F.C.,Jr (1990),"Jealousy on the Job”, Personnel Journal.

Nayar, Raja, NainTara Raja (2012), The Impact of Impression Management Behavior on Organizational Politics Among Male and Female Employees in Organic and Mechanistic Organizational Systems of Pakistan Telecommunication Sector, Interdisciplinary Journal of Contemporary Research in Business, Vol 3, No 9, 914-924

Provis, Chris (2010), The ethics of impression management, Business Ethics: A European Review Volume 19 Number $2.192-212$

Rind, B., \& Benjamin, D. (1993). Effects of public image concerns and self-image on compliance. The Journal of Social Psychology, 134, 19-25.

Rosenfeld, P., Giacalone, R. A., \& Riordan, C. A. (1995). Impression management in organizations. New York: Routledge.pp.50-60

Sallot T, L.M. (2002). What the public thinks about public relations: An impression management experiment. Journalism \& Mass Communication Quarterly, 79 (1), 150-164.

Salovey, Peter, Carussco, David, (2010), Yönetimde Duygusal Zekâ, (çev. S.Kaymak), İstanbul: Crea Yayıncilık.s.107

Silvia, Paul (2006), Emotion Concepts and Self Focused Attention: Exploring Paralel Effects of Emotional States and Emotional Knowledge, s.229-235

Schlenker, B. R. (1980). Impression Management: the self-concept, social identity and interpersonal relations. Belmont, California: Wadworth, Inc.

Sorensen, Jeanne (2008), "Measuring Emotions in a Consumer Desicion-Making-ContextApproaching or Avoiding", Alborg University Department of Business Studies No:20.p.7

Stearns, P.Z.(1986), Anger: The Struggle For Emotional Control In America's History.Chicago: University Of Chicago Press.p.3

Taylor, S. E. (1997). Social psychology. New Jersey: Prentice Hall.

Tedeschi, J. T., \& Melburg, V. (1984). Impression management and influence in the organization.In S.B. Bacharach \&E.J. Lawler (Eds.) Research in the sociology of organizations, vol 3, Greenwich, CT: JAI Press. pp.31-58.

Tedeschi, J. T., \& Riess, M. (1981). Identities, the Phenomenal self, and laboratory research. In Tedeschi J.T.(Ed.), Impression management Theory and SocialPsychological Research.New York: Academic Press, Inc. pp.10-15

Toegel, Ginka (2007), Emotion Helpers: The Role Of High Positive Affectivity and High SelfMonitoring Managers Personnel Psychology, s. 337-365. 